\title{
Target Language Use in Communicative English Lessons: The Emotional Perspective
}

\author{
Takako Inada ${ }^{1,2}$ \\ ${ }^{1}$ Department of Health Sciences, Japan University of Health Sciences, 1961-2 Satte, Satte-shi, Saitama 340-.113, \\ Japan \\ ${ }^{2}$ Department of International Communication, Kanda University of International Studies, 1-4-1, Wakaba, \\ Mihama-ku, Chiba-city, Chiba 261-0014, Japan \\ Correspondence: Takako Inada, Department of Health Sciences, Japan University of Health Sciences, 1961-2 \\ Satte, Satte-shi, Saitama 340-0113, Japan \& Department of International Communication, Kanda University of \\ International Studies, 1-4-1, Wakaba, Mihama-ku, Chiba-city, Chiba 261-0014, Japan.
}

Received: August 24, 2021

Accepted: September 29, 2021

Online Published: October 4, 2021

doi: $10.5539 /$ elt.v14n11p1

URL: https://doi.org/10.5539/elt.v14n11p1

\begin{abstract}
Lessons for developing students' communication skills have been recently introduced to university English education in Japan, and the lesson format has become student-centered. As lessons are given in English and students have more opportunities to practice speaking in English, there are likely to be controversies over the proper balance between the use of the target language (TL) and the first language (L1) in EFL classrooms. However, no clear consensus concerning the relationship between these has been reached yet. The present research investigated the factors that were related to TL/L1 use among Japanese university students. A questionnaire containing background information and a five-point Likert scale of anxiety was filled in by 252 students. Following this, individual interviews with five students were conducted. The results revealed that while the advantages of L1 use for the students were reported, the students had negative feelings about their use of the L1 due to decreasing the contact with the TL and/or increasing peer and self-pressure. Therefore, students should gradually become accustomed to English-only instruction in an unthreatening environment.
\end{abstract}

Keywords: communicative English lessons, EFL college students, foreign language classroom anxiety, peer/self-pressure, TL/L1 use

\section{Introduction}

There is an ongoing debate about whether only the target language (TL) should be used, or whether the first language (L1) use should be allowed in TL acquisition in communicative classes, and this issue remains controversial. In such classes, many Japanese universities stipulate English-only instruction (Rivers, 2011), and many teachers prefer the strategies like pair/group work, and do not approve of students using the L1 (McDonough, 2002). This is because students need to become accustomed to the TL and practice using it in order to learn the TL. However, in an EFL context, both students and teachers share the same L1, and using L1 may seem like an instant resolution in order to ensure accurate understanding. Both TL use and L1 use seem to have advantages respectively. Thus, this study examines the relationship between TL and L1 in more detail by focusing on the psychological viewpoint of students.

\section{Literature Review}

\subsection{The Use of The L1}

L1 use is usually prohibited in communicative classes in EFL contexts in Japan (Rivers, 2011). However, some researchers (Anton \& DiCamilla, 1999; Carson \& Kashihara, 2012; Storch \& Wigglesworth, 2003) have reported that the strategic use of the L1 should not be banned because it has advantages. Students usually wish to participate in activities using the TL but, when they have limited English skills to express their ideas, the students might not be able to join in the TL activities. It is important to note that it is not sufficient for students to simply be exposed to the TL in order to internalize and process the message (Moore, 2010). Therefore, students need to use their L1 as a useful learning tool to enhance their comprehension (Butzkamm, 1998) which, in turn, decreases their anxiety (Rivers, 2011). In Burden's (2000) study, the students hoped that their teachers would use 
the TL, but also hoped that the teachers would use the students' L1 to explain difficult aspects of the content. The use of the L1 in TL conversations is regarded as a general psychological process because the cognitive activities of speaking and thinking are closely linked (Brooks \& Donato, 1994). The L1 assists in the production of the TL and in solving task-related problems. In Edstrom's (2006) study, the use of the L1 was found to be useful when the students could not express their thoughts in the TL, and that the use of the L1 in this situation created good rapport in the classroom. In brief, the use of the L1 appears to have advantages in terms of cultivating better understanding, improving students' language skills, and increasing the smoothness of the conversation.

\subsection{The Use of the TL}

Some studies of language selection have provided different and interesting insights despite some of the advantages of using the L1 in foreign language (FL) communication lessons. Some researchers (Liu \& Jackson, 2008; Turnbull, 2001) have stated that the overuse of the L1 could defeat the aim of increasing communication skills in EFL classes because the amount of the students' contact with the TL would be decreased.

Instead of relying on the use of the L1, these researchers have emphasized the importance of using the TL to create a less intimidating and more natural classroom atmosphere (Scrivener, 2011). In order to increase TL use, teachers can employ pragmatic strategies (Neil, 1997; Chaudron, 1988; Kraemer, 2006). Therefore, teachers should explain that it is important to use the TL as frequently as possible in communication classes and not to rely overly on the L1 to their students (Carless, 2008).

Similarly, some researchers (Oxford \& Ehrman, 1992; Shao et al., 2013; Thompson \& Lee, 2013) have insisted that students should practice speaking the TL more, both inside and outside of the classroom, as their English proficiency improves. The students' increased use of the TL might assist in decreasing their anxiety and increasing their communicative competence (Levine, 2003). In fact, MacIntyre and Mercer (2014), and Saito et al. (2018), reported that the regular and frequent use of the TL, accompanied by feelings of enjoyment, could promote second language acquisition (SLA), decrease anxiety, and improve overall TL proficiency. This is partially in line with Woodrow's (2006) study, which found that anxiety about speaking in the TL could be a significant predictor of poor verbal performances.

\subsection{The Serious Influence of Foreign Language Classroom Anxiety (FLCA)}

There appears to be a relationship between anxiety and language choice (TL or L1) in EFL classrooms. When both students and teachers share the same mother tongue, the use of the L1 can increase the students' understanding of the TL and decrease their anxiety (Weschler, 1997). Horwitz et al. (1986) explained that FLCA was a particular type of anxiety that arose due to the difference between mature thinking and immature communication skills, which subsequently posed a threat to self-confidence. Yan and Horwitz (2008) stated that increasing students' motivation and self-confidence may help to decrease their anxiety levels when learning a language. Although oral communication lessons have been introduced into English education in Japan (Nishino \& Watanabe, 2008), many Japanese college students are not able to communicate in basic English despite having studied English for more than six years prior to entering university (Wicking, 2010). Many universities apply an English-only policy with the aim of improving students' communicative ability. However, an important discussion about the appropriate balance between the use of the TL and the L1 use to reduce students' anxiety and to improve their English proficiency has arisen (Weschler, 1997).

This study focuses on students' language use rather than on teachers' language use. With this in mind, the present study addressed the following research question:

1) What language choices should college students make in communicative EFL classes in order to decrease their anxiety and promote their acquisition of a TL?

\section{Methods}

\subsection{Participants}

The participants in this study were drawn from the classes of seven teachers who gave permission to access their students; the students were attending a co-educational private university located in an urban area. The university had five departments. The teachers used their own discretion to select the texts for their lessons. There were also some differences regarding teaching experience, pedagogic styles, and language choice(s). The university's English program advocated the English-only system, but some teachers and students used the L1 informally when necessary.

The data from 252 students (63 males, 189 females) who were attending communicative English classes at a Japanese university were finally used in the survey. The number of female students was about three times that of 
the male students. This reflected the gender ratio of the university-wide population (about 2880 students). There were about 720 students in each grade; approximately 450 students majored in English, around 150 in Asian languages such as Chinese, Korean, Indonesian, Thai, or Vietnamese, and about 120 in Spanish and Portuguese. The range of the participants' ages was from 18 to 24 years (median age 19, accounting for 86 students). There were 17 seniors, 62 juniors, 68 sophomores, and 105 freshmen. The participants were racially homogeneous; all of them had been raised in Japan and their L1 was Japanese. Only some of the students had begun to learn English at an English conversation school during childhood. Participants who majored in languages other than English were also required to study English as an L2. The 108 participants who had begun to study a third language for their majors (L3) after entering the university included 61 students who were studying Asian languages such as Chinese, Korean, Thai, Indonesian, and Vietnamese, and 47 students who were studying Spanish or Portuguese. Bilingual native Japanese-speaking teachers taught the Test of English as a Foreign Language (TOEFL) preparation classes (semi-required English classes; 129 students attended), and a native English-speaking teacher taught the communication class (an optional English class; 123 students attended).

With regard to the experience of having studied in an English-speaking country $(n=252$; median $=0), 148$ students did not have any experience of studying abroad or of studying abroad for more than one week, while 104 students had studied abroad for periods ranging from one week to 60 weeks (median: one week). The university's syllabus emphasized verbal communication, but the participants' opportunities to speak English outside of the classroom ranged from 0 to 40 hours per week (median: 0). Only one student spoke English for forty hours per week during her part-time job of teaching English. Most of the students had insufficient amounts of speaking practice outside of class. The students in the required classes $(n=129$; mean $=0.84$ hours per week; $\mathrm{SD}=1.77$; range $=0-12$ ) spent significantly less time per week speaking English outside of class than did the students in the optional English classes $(\mathrm{n}=123$; mean $=1.83$ hours per week; $\mathrm{SD}=4.61$; range $=0-40 ; \mathrm{t}=$ $-2.27, \mathrm{p}=.001$, Cohen's $\mathrm{d}=.62$ ). The participants' hours of English study apart from speaking ranged from 0 to 30 hours (median: 3 ) per week outside of the classroom (mainly at home).

\subsection{The Questionnaire and the Interview}

The participating students completed the paper-based questionnaire that included background information and a five Likert scale questionnaire of FLCA within about 10 minutes during class time. The five-item FLCA questionnaire (Cronbach alpha $=.89$ ) by Saito and Samimy (1996), who adapted Gardner's (1985) FLCA scale, was used. The questionnaire also included demographic information and basic educational variables concerning English such as gender, age, years at college, nationality, native language, department (major), class type (required or optional), experience of having studied abroad, frequency of speaking English outside of class per week (minutes per week), and frequency of self-studying English after school per week (minutes per week; see Appendix A). The Cronbach's alpha value for five anxiety items was 0.758 , and the levels of anxiety were $\mathrm{n}=$ 252 ; min. 8; max. 25; mean $=17.56$; S.D. $=3.788$ in this study.

Five female students voluntarily participated in the individual interviews (for about 15 minutes on the campus), which were conducted to examine the relationship between TL and L1 use in the lessons. The interview question was "What should be done with regard to language choice to reduce anxiety and improve students' FL acquisition?" Each interview was conducted in Japanese while taking notes and recording audio to ensure that the participants could state their actual opinions and experiences precisely without any communication difficulties due to having limited proficiency in English.

\subsection{Data Analysis}

The characteristics of the participants and the relationships among some variables were analyzed using the SPSS statistical package version 23 ( $\mathrm{p}<0.05$ : statistically significant). Bonferroni's correction was applied to control for the overall Type I error rate when multiple comparisons were conducted. The interview responses were transcribed, translated into English, and coded; the data were then analyzed. Based on the factors identified by previous researchers, the following categories were coded: TL use (Shao et al., 2013), L1 use (Rivers, 2011), FLCA (Horwitz et al., 1986), motivation (Yan \& Horwitz, 2008), and self-confidence (Bai et al., 2019).

\section{Results}

\subsection{The Individual Interviews}

In order to investigate which language should be used to decrease their anxiety and promote their English acquisition, the students were asked to express their opinions about their language choice(s) during the interviews. The results of the individual interview survey revealed controversial opinions. Interesting quotes from students about the use of the TL/L1 in communicative English classes are summarized in Table 1. 
Table 1. The Results of Individual Interviews

\begin{tabular}{|c|c|c|}
\hline & Neutral & Pro TL use \\
\hline Anxiety & $\begin{array}{l}\text { If students can use Japanese for the difficult parts and } \\
\text { English for the easy parts, they can practice speaking } \\
\text { English without feeling anxious or guilty and develop } \\
\text { their ability to speak in English. It is not good to feel } \\
\text { guilty even when students have no choice but to use } \\
\text { Japanese for the difficult parts. For students' } \\
\text { Japanese use, students intensify such negative } \\
\text { feelings and teachers see it as evidence of a lack of } \\
\text { motivation. Teachers should not expect too much } \\
\text { from students and should give them assignments that } \\
\text { are within their capabilities. (1) \#3;2) F; 3) 1; 4) } 11 \text {; } \\
\text { 5) English) }\end{array}$ & $\begin{array}{l}\text { Students with high anxiety often use Japanese } \\
\text { when experiencing difficult situations, but this } \\
\text { habit prevents them from improving their } \\
\text { English skills. This is because, while L1 can } \\
\text { reduce short-term anxiety, it cannot reduce } \\
\text { long-term anxiety. When a teacher uses } \\
\text { Japanese in class, students worry that their } \\
\text { listening skills will not improve and also } \\
\text { distrust the teachers' English skills. Therefore, } \\
\text { teachers should help students in Japanese } \\
\text { only when needed. (1) \#1;2) F; 3) 2; 4) 8; 5) } \\
\text { Spanish) }\end{array}$ \\
\hline $\begin{array}{l}\text { Self-confidence } \\
\& \text { Motivation }\end{array}$ & $\begin{array}{l}\text { Some classmates encourage me to understand English } \\
\text { without Japanese intervention, but I understand and } \\
\text { speak English through my mother tongue, Japanese. } \\
\text { Using only English increases stress and anxiety, } \\
\text { decreases motivation, and I lose my identity. } \\
\text { Motivation, self-confidence, and the amount of L1 use } \\
\text { are closely related to each other. Students who are } \\
\text { motivated and have high self-confidence do not use } \\
\text { Japanese, while those who are motivated but lack } \\
\text { self-confidence use Japanese. It seems important to } \\
\text { have self-confidence and, for increased } \\
\text { self-confidence, students need to practice speaking } \\
\text { English. (1) \#4; 2) F; 3) 1; 4) 18; 5) English) } \\
\text { I practice speaking English in class as much as } \\
\text { possible, because I understand that the only } \\
\text { opportunity to speak English is in the classroom. } \\
\text { However, when trying to accurately convey detailed } \\
\text { nuances that are difficult to express in English, I } \\
\text { prefer to use Japanese. If I try my best, I may be able } \\
\text { to get my classmates and teachers to understand my } \\
\text { true feelings, but I am not confident in my own } \\
\text { speaking ability. (1) \#5; 2) F; 3) 1; 4) 18; 5) English) }\end{array}$ & $\begin{array}{l}\text { When I try my best to answer in English, but } \\
\text { my classmates immediately answer in } \\
\text { Japanese, I lose motivation because I feel that } \\
\text { my efforts are useless. (1) \#2; 2) F; 3) 2; 4) } 11 \text {; } \\
\text { 5) English) }\end{array}$ \\
\hline
\end{tabular}

Note. 1) I.D.\#; 2) Gender (M/F); 3) Academic year (1 = freshman, 2 = sophomore, 3 = junior, $4=$ senior $)$; 4) Anxiety levels from 8 (lowest) to 25 (highest); 5) Language major

\section{Discussion}

\subsection{Comprehension}

Essentially, the teachers did not use the L1 often, but the students did (McDonough, 2002). It would be ideal for both teachers and students to make the best use of the TL. In particular, students should be comfortable with English-only classes in order to improve their English skills (Levine, 2003); students should only use the L1 to clarify, as the overuse of the L1 will reduce their opportunities to use the TL (Kharma \& Hajjaj, 1989). In the current research, the use of the $\mathrm{L} 1 \mathrm{had}$ several advantages. If the students could use a limited amount of the L1 in the sections they found difficult, it would ultimately become easier for them to speak in English. Moreover, the students felt that they could express subtle emotions with the help of the L1. However, according to the students who were against the overuse of Japanese, if the students relied on Japanese every time they experienced difficulty, their English would not improve because they would not have the opportunity to practice speaking in English. This confirmed Willis' (1981) suggestion that the exclusive use of the TL would allow the students to subconsciously practice their language skills, begin to think in English, and decrease the amount of interference from the L1. Of interest, the students in this study were suspicious of the teaching abilities and motivations of teachers who used an extensive amount of Japanese in the class. This is in line with Chaudron (1988), who said that teachers should be 
encouraged to modify input in the TL by incorporating repetition, basic vocabulary, and slow speech. In general, excessive use of the L1 could contradict the objective of improving communicative abilities (Willis, 1981). In communication classes, teachers may prefer English classes to be taught in English because it is important to be able to communicate in the TL (Wilkerson, 2008).

\subsection{Peer Pressure}

TL use was seen as being advantageous in terms of providing the students with confidence, enjoyment, satisfaction, and motivation as a result of being able to communicate successfully, even though the amount of language was limited (MacDonald, 1993). Some complex aspects in the dynamics of the classroom were revealed in this study. Some students preferred to use Japanese because they considered themselves to be poor English speakers and lacked self-confidence; they felt extremely anxious about communicating solely in English, and thought that they would not be able to make others understand what they were saying correctly, while some of the participants were offended by their classmates taking the easy option of using the L1, which caused them to lose their motivation to make the effort to communicate solely in English. Therefore, it is vital for teachers to not only enhance their students' self-confidence (Bai et al., 2019; Piniel \& Csizer, 2013, van Batenburg et al., 2019), but also increase their motivation (Ahlquist, 2019; Young, 1991; Zhang, 2019).

\subsection{Self-Pressure (Feelings of Guilt)}

L1 use may result in the loss of valuable opportunities for communication (Harbord, 1992). The students in the current study reported feelings of anxiety when they lost the opportunity to speak English because they were concerned that their English-language development might be delayed, and experienced feelings of guilt about having used the L1. This is in line with Stern (1996), who proposed that the use of the L1 in EFL communicative classrooms should be limited to compensate for the fact that students rarely use the TL outside of class. In fact, it is difficult to avoid using the L1 in an EFL context unless the students are willing to stop using it. Moreover, in this study, the teachers made the students feel guilty about using the L1 because the teachers saw the students as lazy people who were not making sufficient effort to speak English. As Krashen (1981) said, teachers should have reasonable expectations regarding their students and should choose appropriate materials for them. For example, they should select tasks and materials that the students are able to complete successfully. Such lessons would assist the students to increase their English skills (Jordan \& Gray, 2019; Sakai \& Kikuchi, 2009). In fact, one student in the present research reported that the teacher's impression that the students were not striving to do their best would cause them to develop negative feelings.

\section{Conclusion}

The results of this research revealed that there were some positive opinions about the use of the L1. The strategic use of the L1 could be beneficial in terms of psychological and cognitive assistance. However, the use of the L1 might have a negative influence on the students' TL development. When they were allowed to use their L1, the students tended to see this as an easy option although they felt that it hindered their progress and increased their anxiety. The students who often used the L1 irritated their peers and decreased their motivation. The students also felt guilty about using the L1 because they missed out on the rare opportunity to speak the TL. In brief, teachers may need to consider the feelings of their students and only allow them to use Japanese to help each other when they feel it is really necessary. However, a better approach would be for the students to make a concerted effort to use the TL in communicative lessons if they aim to be accomplished language learners and to promote their acquisition of an FL.

\section{References}

Ahlquist, S. (2019). Motivating teens to speak English through group work in Storyline. ELT Journal, 73(4), 387-395. https://doi.org/10.1093/elt/ccz023

Anton, M., \& DiCamilla, F. J. (1999). Socio-cognitive function of L1 collaborative interaction in the L2 classroom. The Modern language Journal, 83(2), 233-247. https://doi.org/10.1111/0026-7902.00018

Bai, B., Chao, G. C. N., \& Wang, C. (2019). The relationship between social support, self-efficacy, and English language learning achievement in Hong Kong. TESOL Quarterly, 53(1), 208-221. https://doi.org/10.1002/tesq.439

Brooks, F. B., \& Donato, R. (1994). Vygotskyan approaches to understanding foreign language learner discourse during communicative tasks. Hispania, 77(2), 262-274. https://doi.org/10.2307/344508 
Burden, P. (2000). The use of the students' mother tongue in monolingual English conversation classes in Japan: Some pedagogical arguments. The Language Teacher Online. Retrieved from https://jalt-publications.org/old_tlt/articles/2000/06/burden

Butzkamm, W. (1998). Code-switching in a bilingual history lesson: The mother tongue as a conversational lubricant. International Journal of Bilingual Education and Bilingualism, 1(2), 81-99. https://doi.org/10.1080/13670059808667676

Carless, D. (2008). Student use of the mother tongue in the communicative classroom. ELT Journal, 62(4), 331-338. https://doi.org/10.1093/elt/ccm090

Carson, E., \& Kashihara, H. (2012). Using the L1 in the L2 classroom: The students speak. The Language Teacher, 36(4), 41-48. https://doi.org/10.37546/JALTTLT36.4-5

Chaudron, C. (1988). Second language classrooms: Research on teaching and learning. Cambridge University Press. https://doi.org/10.1017/CBO9781139524469

Edstrom, A. (2006). L1 use in the L2 classroom: One teacher's self-evaluation. The Canadian Modern Language Review, 63(2), 275-292. https://doi.org/10.3138/cmlr.63.2.275

Gardner, R. C. (1985). Social psychology and second language learning: The role of attitudes and motivation. Edward Arnold.

Harbord, J. (1992). The use of the mother tongue in the classroom. ELT Journal, 46(4), 350-355. https://doi.org/10.1093/elt/46.4.350

Horwitz, E. K., Horwitz, M. B., \& Cope, J. (1986). Foreign language classroom anxiety. The Modern Language Journal, 70(2), 125-132. https://doi.org/10.1111/j.1540-4781.1986.tb05256.x

Jordan, G., \& Gray, H. (2019). We need to talk about coursebooks. ELT Journal, 73(4), 438-446. https://doi.org/10.1093/elt/ccz038

Kharma, N. N., \& Hajjaj, A. H. (1989). Use of the mother tongue in the ESL classroom. International Review of Applied Linguistics in Language Teaching, 27(3), 223-235.

Kraemer, A. (2006). Teachers' use of English in communicative German language classrooms: A qualitative analysis. Foreign Language Annals, 39(3), 435-450. https://doi.org/10.1111/j.1944-9720.2006.tb02898.x

Krashen, S. D. (1981). Second language acquisition and second language learning. Pergamon Press Plc.

Levine, G. S. (2003). Student and instructor beliefs and attitudes about target language use, first language use, and anxiety: Report of a questionnaire study. The Modern Language Journal, 87(3), 343-364. https://doi.org/10.1111/1540-4781.00194

Liu, M., \& Jackson, J. (2008). An exploration of Chinese EFL learners' unwillingness to communicate and foreign language anxiety. The Modern language Journal, 92(1), 71-86. https://doi.org/10.1111/j.1540-4781.2008.00687.x

MacDonald, C. (1993). Using the target language. Mary Glasgow Publications.

MacIntyre, P. D., \& Mercer, S. (2014). Introducing positive psychology to SLA. Studies in Second Language Learning and Teaching, 4(2), 153-172. https://doi.org/10.14746/ssllt.2014.4.2.2

McDonough, J. (2002). The teacher as language learner: Worlds of difference? ELT Journal, 56(4), 404-411. https://doi.org/10.1093/elt/56.4.404

Moore, D. (2010). Code-switching and learning in the classroom. International Journal of Bilingual Education and Bilingualism, 5(5), 279-293. https://doi.org/10.1080/13670050208667762

Neil, P. S. (1997). Reflections on the target language. Center for Information on Language Teaching and Research.

Nishino, T., \& Watanabe, M. (2008). Communication-oriented policies versus classroom realities in Japan. TESOL Quarterly, 42(1), 133-138. https://doi.org/10.1002/j.1545-7249.2008.tb00214.x

Oxford, R. L., \& Ehrman, M. (1992). Second language research on individual differences. Annual Review of Applied Linguistics, 13, 188-205. https://doi.org/10.1017/S0267190500002464

Piniel, K., \& Csizer, K. (2013). L2 motivation, anxiety and self-efficacy: The interrelationship of individual variables in the secondary school context. Studies in Second Language Learning and Teaching, 3(4), 523-550. https://doi.org/10.14746/ssllt.2013.3.4.5 
Rivers, D. J. (2011). Politics without pedagogy: Questioning linguistic exclusion. ELT Journal, 65(2), 103-113. https://doi.org/10.1093/elt/ccq044

Saito, K., Dewaele, J.-M., Abe, M., \& In'nami, Y. (2018). Motivation, emotion, learning experience, and second language comprehensibility development in classroom settings: A cross-sectional and longitudinal study. Language Learning, 68(3), 709-743. https://doi.org/10.1111/lang.12297

Saito, Y., \& Samimy, K. K. (1996). Foreign language anxiety and language performance: A study of learner anxiety in beginning, intermediate, and advanced-level college students of Japanese. Foreign Language Annals, 29(2), 239-249. https://doi.org/10.1111/j.1944-9720.1996.tb02330.x

Sakai, H., \& Kikuchi, K. (2009). An analysis of demotivators in the EFL classroom. System, 37, 57-69. https://doi.org/10.1016/j.system.2008.09.005

Scrivener, J. (2011). Learning teaching: The essential guide to English language teaching (3rd ed.). Macmillan.

Shao, K., Yu, W., \& Ji, Z. (2013). An exploration of Chinese EFL students' emotional intelligence and foreign language anxiety. The Modern Language Journal, 97(4), 917-929. https://doi.org/10.1111/j.1540-4781.2013.12042.x

Stern, H. H. (1996). Issues and options in language teaching. Oxford University press.

Storch, N., \& Wigglesworth, G. (2003). Is there a role for the use of the L1 in an L2 setting? TESOL Quarterly, 37(4), 760-770. https://doi.org/10.2307/3588224

Thompson, A. S., \& Lee, J. (2013). Anxiety and EFL: Does multilingualism matter? International Journal of Bilingual Education and Bilingualism, 16(6), 730-749. https://doi.org/10.1080/13670050.2012.713322

Turnbull, M. (2001). There is a role for the L1 in second and foreign language teaching, but... The Canadian Modern Language Review, 57(4), 531-540. https://doi.org/10.3138/cmlr.57.4.531

van Batenburg, E. S. L. V., Oostdam, R. J., Gelderen, A. J. S. V., Fukkink, R. G., \& Jong, N. H. D. (2019). Oral interaction in the EFL classroom: The effects of instructional focus and task type on learner affect. The Modern Language Journal, 103(1), 308-326. https://doi.org/10.1111/modl.12545

Weschler, R. (1997). Uses of Japanese in the English classroom: introducing the Functional-Translation method. Kyoritsu Women's University Department of International Studies Journal, (12), 87-110. Retrieved from https://eric.ed.gov/?id=ED422746

Wicking, P. (2010). Transforming textbook activities into successful tasks. In A. M. Stoke (Ed.), Proceedings of JALT Conference, 2009 (pp. 466-473). Tokyo: JALT.

Wilkerson, C. (2008). Instructors' use of English in the modern language classroom. Foreign Language Annals, 41(2), 310-320. https://doi.org/10.1111/j.1944-9720.2008.tb03294.x

Willis, J. (1982). Teaching English through English: A course in classroom language and techniques (Longman Handbooks for Language Teachers Series). Longman ELT.

Woodrow, L. (2006). Anxiety and speaking English as a second language. RELC Journal, 37(3), 308-328. https://doi.org/10.1177/0033688206071315

Yan, J. X., \& Horwitz, E. K. (2008). Learners' perceptions of how anxiety interacts with personal and instructional factors to influence their achievement in English: A qualitative analysis of EFL learners in China. Language Learning, 58(1), 151-183. https://doi.org/10.1111/j.1467-9922.2007.00437.x

Young, D. J. (1991). Creating a low-anxiety classroom environment: What does language anxiety research $\begin{array}{lllll}\text { suggest? The Modern } & \text { Language Journal, }\end{array}$ https://doi.org/10.1111/j.1540-4781.1991.tb05378.x

Zhang, X. (2019). Foreign language anxiety and foreign language performance: A meta-analysis. The Modern Language Journal, 103(4), 763-781. https://doi.org/10.1111/modl.12590 


\section{Appendix}

\section{A Paper-based Questionnaire}

\section{A Five-point Likert scale questionnaire}

A1. It embarrasses me to volunteer answers in English class.

A2. I feel confident when I speak in English class.

A3. I always feel that the other students are speaking English better than I do.

A4. I do not get nervous and confused when I am speaking in English class.

A5. I care what other students think of me when I speak English.

The five-point Likert scale ranged from strongly disagree $=1$, disagree $=2$, neither agree nor disagree $=3$, agree $=4$, to strongly agree $=5$, with lower scores indicating lower levels in each category. Two of these items were phrased negatively to prevent the aim of the research from being detected by the participants. These items were reverse coded when entered into in an Excel file.

\section{Background information}

1. Gender: Male; $\quad$ Female

2. Age: $\quad$ years old

3. Years at college: Freshman Sophomore Junior Senior

4. Nationality:

5. Native language:

6. Department (Major):

7. Class type: required optional

8. Have you ever studies in a country where English is spoken? If yes, how many day(s) in total?

$$
\text { Yes: day(s); No }
$$

9. Do you have the opportunities to speak English outside the classroom nowadays? If yes, how many minutes in total per week? Yes: minutes per week; No

10. How many minute(s) do you study English after school per week recently? minutes a week

\section{Copyrights}

Copyright for this article is retained by the author(s), with first publication rights granted to the journal.

This is an open-access article distributed under the terms and conditions of the Creative Commons Attribution license (http://creativecommons.org/licenses/by/4.0/). 